\title{
Synergistic effect of phytochemicals on cholesterol metabolism and lipid accumulation in HepG2 cells
}

Ennian Leng ${ }^{1 \dagger}$, Yuan Xiao ${ }^{1,2+}$, Zhentao Mo ${ }^{1}$, Yiqi Li ${ }^{1}$, Yueyue Zhang ${ }^{1}$, Xiaosi Deng ${ }^{1}$, Min Zhou', Chaochao Zhou', Zengxuan $\mathrm{He}^{1}$, Jingyi $\mathrm{He}^{1}$, Lu Xiao ${ }^{1}$, Junming $\mathrm{Li}^{1}$ and Wenna $\mathrm{Li}^{1^{*}}$

\begin{abstract}
Background: Crocin (CRO), chlorogenic acid (CGA), geniposide (GEN), and quercetin (QUE) are all natural compounds with anti-obesity properties, in particular, hypolipidemic effects, which have been widely used for the treatment of obesity-related metabolic diseases. However, it is not yet known whether these compounds interact synergistically. Here, we investigated the effects and molecular mechanisms of CRO, CGA, GEN, QUE, and a combination of all four compounds (CCGQ), on lipid accumulation in human hepatoma (HepG2 cells).

Methods: The optimal concentration of CRO, CGA, GEN, QUE to stimulate HepG2 cells proliferation was determined using MTT assay. HepG2 cells were pretreated with $10 \mu \mathrm{mol} / \mathrm{L}$ simvastatin, $1 \mu \mathrm{mol} / \mathrm{L} C R O, 30 \mu \mathrm{mol} / \mathrm{L} \mathrm{CGA}, 10 \mu \mathrm{mol} /$ $\mathrm{L}$ GEN, $10 \mu \mathrm{mol} / \mathrm{L}$ QUE, and CCGQ (a combination of $1 \mu \mathrm{mol} / \mathrm{L} C R O, 30 \mu \mathrm{mol} / \mathrm{L} \mathrm{CGA}, 10 \mu \mathrm{mol} / \mathrm{L} \mathrm{GEN}$, and $10 \mu \mathrm{mol} /$ L QUE) for 24 or 48 h. Oil red O staining and extracellular TC and TG levels were detected. The RT-PCR was used to observe on cholesterol metabolism-related gene expression. Immunocytochemistry and western-blot assayed the 3hydroxy-3-methylglutaryl-coenzyme (HMGCR) protein expression in HepG2 cells.
\end{abstract}

Results: Compared to those of control, we demonstrated that treating HepG2 cells for $48 \mathrm{~h}$ with CCGQ resulted in a strong synergistic effect, causing a marked decrease in lipid deposition in comparison to individual treatments, in both triglyceride and total cholesterol (CRO, 5.74- and 1.49-folds; CGA, 3.38- and 1.12-folds; GEN, 4.04- and 1.44folds; QUE, 3.36- and 1.24-folds; simvastatin, 5.49- and 1.83-folds; and CCGQ, 7.75- and 2.20-folds), and Oil red O staining assays. In addition, CCGQ treatment increased ATP-binding cassette transporter (ABCA1), cholesterol 7ahydroxylase (CYP7A1), and AMP-activated protein kinase 2a (AMPKa2) mRNA expression, while decreasing sterol regulatory element binding protein 2 (SREBP2), and liver X receptor alpha (LXRa) mRNA expression. Notably, CCGQ was more effective in decreasing HMGCR expression than the individual treatments.

Conclusion: The CCGQ combination has potential, both as a complementary therapy for hyperlipemia, and in preventing further obesity-related complications.

Keywords: Crocin, Chlorogenic acid, Geniposide, Quercetin, Synergistic interaction, Lipid accumulation

\footnotetext{
* Correspondence: lielizabeth@126.com

tEqual contributors

'Zhuhai Campus, Zunyi Medical University, Jinwan District, Zhuhai 519041,

Guangdong, China

Full list of author information is available at the end of the article
} International License (http://creativecommons.org/licenses/by/4.0/), which permits unrestricted use, distribution, and reproduction in any medium, provided you give appropriate credit to the original author(s) and the source, provide a link to the Creative Commons license, and indicate if changes were made. The Creative Commons Public Domain Dedication waiver (http://creativecommons.org/publicdomain/zero/1.0/) applies to the data made available in this article, unless otherwise stated. 


\section{Background}

Obesity has become a global epidemic which is strongly associated with many metabolic diseases, such as coronary heart disease, type 2 diabetes mellitus, and nonalcoholic fatty liver disease $[1,2]$. Effective long-term solutions to reduce obesity have remained elusive until now. Many obesity-related metabolic abnormalities are characterized by dyslipidemia, in particular the formation of excessive lipid deposits in non-adipose tissue, such as the liver. These deposits cause lipotoxicity, resulting in tissue damage, fibrosis and potential organ failure [3]. There have been numerous investigations into the role of dyslipidemia in the pathophysiology of obesity $[4,5]$. Decreasing hyperlipemia is therefore considered a protective strategy to treat obesity-induced diseases [6, 7].

In the last decade, many studies have focused on a variety of natural products, including botanical extracts or phytochemicals, for the prevention and treatment of obesity. In these studies, phenolic compounds and carotenoids have attracted a great deal of interest. Phenolic compounds, such as phenolic acids and flavonoids, have pharmacological properties involved in the regulation of plasma lipids, and are increasingly being studied [8]. Crocin (CRO) is the only water-soluble carotenoid in nature, and has been shown to be effective in reducing diet-induced obesity in animals, as well as improving the blood lipid profile $[9,10]$. Chlorogenic acid (CGA), ubiquitously found in plants, is a phenolic acid, which has been shown to exert anti-obesity effects and improve lipid metabolism [11]. It has been reported that hypocholesterolemic effects are the primary benefit of CGA treatment [12]. Geniposide (GEN), an iridoid glycoside, has also recently been demonstrated to infer protective effects against hyperlipemia and obesity in rats [13]. Quercetin (QUE), commonly found in glycosidic form in plants, is the most abundant flavonoid in the typical human diet, and exerts anti-obesity activity through a range of molecular pathways [14, 15].

Gardenia jasminoides Ellis (gardenia) fruit, of the Rubiaceae family, was reported to decrease body weight, fat percentage, and BMI, lower high insulin, GLP-1, and leptin levels, and reduce insulin resistance in middleaged obese women. It has been reported that CRO, CGA, rutin, and GEN are the main components of gardenia fruit [16]. The anti-obesity effect of gardenia fruit may be attributed to synergistic interactions between its various phytochemical constituents, and analyzing the activity of these active components is a key step to understanding this effect and underlying mechanisms. It is therefore necessary to study the impact of the combination of these compounds on dyslipidemia, but no study has so far focused on this. Rutin is the most common, and important, glycosidic form of QUE [15] and cellular models can clarify how these phytochemicals interfere with lipid metabolism to prevent obesity at the molecular level. This study therefore aimed to investigate hypolipidemic effects and molecular mechanisms of combined therapy with CRO, CGA, GEN, and QUE in human hepatoma HepG2 cells.

\section{Methods \\ Chemicals}

CGA, GEN and QUE (purity > 98\%, as determined by HPLC) were purchased from the National Institute for the Control of Pharmaceutical and Biological Products (Beijing, China). CRO was extracted and purified as previously reported (purity $>98 \%$, as determined by HPLC) [17]. All drugs were dissolved in $0.1 \%$ dimethyl sulfoxide (DMSO). The chemical structures of purified CRO, CGA, GEN, and QUE are illustrated in Fig. 1. All other chemicals used were of molecular biology and analytical grade.

\section{Cell culture}

The HepG2 human hepatoma cell line was purchased from the China Center for Type Culture Collection. HepG2 cells were grown and maintained in RPMI-1640 medium (Invitrogen, Waltham, MA) supplemented with $10 \%$ fetal bovine serum, $100 \mathrm{U} / \mathrm{mL}$ penicillin, and $100 \mu \mathrm{g} / \mathrm{mL}$ streptomycin at $37{ }^{\circ} \mathrm{C}$ in a humidified atmosphere of $5 \% \mathrm{CO}_{2}$. Cells were subcultured upon reaching approximately $80-90 \%$ confluency.

\section{Cell viability assay}

HepG2 cell growth was determined using the MTT assay. Cells $\left(2 \times 10^{4}\right)$ were seeded into 96 well microtiter plates containing $100 \mu \mathrm{L}$ complete culture medium per well, and incubated for $24 \mathrm{~h}$ at $37{ }^{\circ} \mathrm{C}$. Cultures were transferred into serum-free medium $12 \mathrm{~h}$ prior to performing the assay. A range of concentrations of CRO ( 0 . 01, 0.1, 1, 10, and $100 \mu \mathrm{mol} / \mathrm{L})$, CGA $(0.3,3,30,300$, and $3000 \mu \mathrm{mol} / \mathrm{L}), \operatorname{GEN}(0.1,1,10,100$, and $1000 \mu \mathrm{mol} /$ L), and QUE (1, 10, 20, 40, 60, 80, and $100 \mu \mathrm{mol} / \mathrm{L})$ were added. Cells were incubated for a further 24 or $48 \mathrm{~h}$ in an incubator $\left(37{ }^{\circ} \mathrm{C}\right.$ at $\left.5 \% \mathrm{CO}_{2}\right)$, and then treated with MTT for $4 \mathrm{~h}$. DMSO $(150 \mu \mathrm{L})$ was added to each well, and plates were then shaken for $10 \mathrm{~min}$. Absorbance was measured at $490 \mathrm{~nm}$ using a microplate reader (BioRad). Cell viability in each group was presented as a percentage of the control.

\section{Oil red $\mathrm{O}$ staining and determination of extracellular TC and TG levels}

HepG2 cells $\left(2 \times 10^{4}\right)$ were seeded into 6- or 24-well plates and cultured. After incubation in the presence or absence of the different drugs for $48 \mathrm{~h}$, cells were fixed with $4 \%$ polyformaldehyde, and then incubated in Oil 


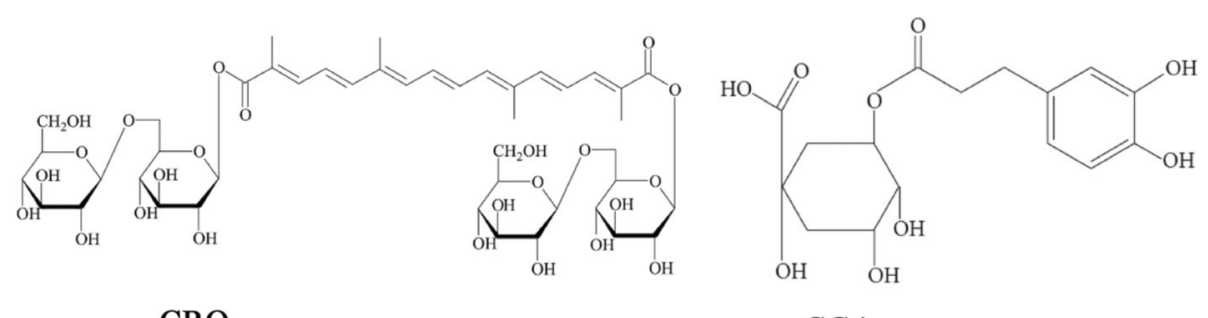

CRO

CGA

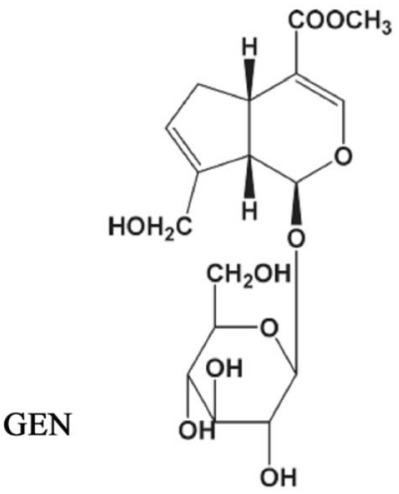<smiles>O=c1c(O)c(-c2ccc(O)c(O)c2)oc2cc(O)cc(O)c12</smiles>

QUE

Fig. 1 Chemical structures of CRO, CGA, GEN and QUE

red O working solution for $30 \mathrm{~min}$. Microscopic images were taken to visualize red oil droplets with an Olympus microscope (Olympus Corporation, Tokyo, Japan). After incubation in the presence or absence of the different drugs for either 24 or $48 \mathrm{~h}$, cell supernatant was used for analysis of total cholesterol (TC) and triacylglycerol (TG) levels. TC and TG kits (Beihuakangtai, Beijing, China) were used according to the manufacturer's instructions.

\section{RT-PCR}

Expression of the following genes was studied using semi-quantitative RT-PCR: ATP-binding cassette transporter (ABCA1), sterol regulatory element binding protein 2 (SREBP2), cholesterol 7 $\alpha$-hydroxylase (CYP7A1), liver $\mathrm{X}$ receptor alpha $(\mathrm{LXR} \alpha)$, AMP-activated protein kinase $2 \alpha$ (AMPK $\alpha 2)$ and 3-hydroxy-3-methylglutarylcoenzyme A reductase (HMGCR). Primer pairs (Sangon,
Shanghai, China) are listed in Table 1. RNA isolation (Total RNA Extractor, Sangon, Shanghai, China), cDNA synthesis (TaKaRa PrimeScript ${ }^{\mathrm{Tm}}$ RT reagent Kit, Baosheng, Dalian, China), and amplification (TaKaRa Ex Taq PCR Kit, Baosheng, Dalian, China) were performed as per manufacturer's instructions. Amplification was performed using a three step temperature cycle as follows: ABCA1, AMPK $\alpha 2$, and HMGCR: 32 cycles at $95^{\circ}$ $\mathrm{C}$ for $20 \mathrm{~s}, 57{ }^{\circ} \mathrm{C}$ for $30 \mathrm{~s}$, and $72{ }^{\circ} \mathrm{C}$ for $45 \mathrm{~s}$; SREBP2, LXR $\alpha$, and glyceraldehyde-3-phosphate dehydrogenase (GAPDH): 32 cycles at $95{ }^{\circ} \mathrm{C}$ for $20 \mathrm{~s}, 56{ }^{\circ} \mathrm{C}$ for $30 \mathrm{~s}$, and $72{ }^{\circ} \mathrm{C}$ for $45 \mathrm{~s}$; and CYP7A1: 32 cycles at $95{ }^{\circ} \mathrm{C}$ for $20 \mathrm{~s}, 58{ }^{\circ} \mathrm{C}$ for $30 \mathrm{~s}$ and $72{ }^{\circ} \mathrm{C}$ for $30 \mathrm{~s}$. Polymerization was performed at $72{ }^{\circ} \mathrm{C}$ for $5 \mathrm{~min}$. Amplified product was analyzed in 1\% agarose gel, photographed, and analyzed using Quality One Software (SPSS Inc., Chicago, IL). Each relative densitometric value was calculated after normalization to GAPDH.

Table 1 The primers of gene amplification

\begin{tabular}{|c|c|c|c|}
\hline GENE & Sense & Anti-sense & Product \\
\hline $\mathrm{ABCA} 1$ & 5'-AGGCCCAGACCTGTAAATGC-3' & 5'-CTCACCAACCTTGCCAACTTC-3' & $450 \mathrm{bp}$ \\
\hline SREBP2 & $5^{\prime}-$ CAGACGCCAAGATGCACAAG-3' & 5'-TGGCTCATCTTTGACCTTTGC-3' & $323 \mathrm{bp}$ \\
\hline CYP7A1 & 5'-CATTTGGGCACAGAAGCATTG-3' & 5'-AGGCAGCGGTCTTTGAGTTAG-3' & $174 \mathrm{bp}$ \\
\hline NR1H3 (LXR a) & 5'-AAGAAACTGAAGCGGCAAGA-3' & 5'-AGCAATGAGCAAGGCAAACT-3' & $555 \mathrm{bp}$ \\
\hline PRKAA2 (AMPK a2) & 5'-TCAATCGTTCTGTCGCCAC-3' & 5'-ATACGGTTTGCTCTGACTTCG-3' & $530 \mathrm{bp}$ \\
\hline HMGCR & 5'-CTCCGCAGGCTATTTGTTCAG-3' & 5'-GCTAAGAGCGTTCGTGGGTC-3' & $620 \mathrm{bp}$ \\
\hline GAPDH & 5'-ACTCCTCCACCTTTGACGCTG-3' & 5'-CTCTCTTCCTCTTGTGCTCTTGC-3' & $182 \mathrm{bp}$ \\
\hline
\end{tabular}




\section{Immunocytochemistry}

HepG2 cells were plated into 6-well chamber slides. After treatment with the different drugs for $48 \mathrm{~h}$, the slides were fixed in $4 \%$ neutral buffered paraformaldehyde for $30 \mathrm{~min}$ at room temperature, subsequent HMGCR detection. Immunostaining was carried out using a kit (Boaoseng, Beijing, China, SP-0023). The endogenous peroxidase was inactivated by treated the slides with $0.3 \%$ hydrogen peroxide for $10 \mathrm{~min}$. After washed with PBS, the slides were added into normal goat serum to incubate for $10 \mathrm{~min}$ at $37^{\circ} \mathrm{C}$. Rabbit polyclonal HMGCR antibody (1:50) (Boaoseng, Beijing, China, LOT. YE0905W, bs-5068R) was used as the primary antibody to incubated cells at $4{ }^{\circ} \mathrm{C}$ for overnight after washed. The slides were washed and incubated with biotinylated secondary antibody for $30 \mathrm{~min}$. And then slides were added into peroxidase-labeled streptavidin for another $30 \mathrm{~min}$. Slides were stained with 3,3' -diaminobenzidine for $25 \mathrm{~min}$. Cells were incubated with nonimmune serum or PBS to control antibody specificity, and then the nuclei were counterstained with H\&E.

\section{Western blot}

Total cell protein from each sample was extracted using a kit (Protease inhibitor cocktail set I, Calbiochem, USA) and quantified using a Bio-Rad protein kit (Pierce, Rockford, IL). Equal quantities of protein were separated using 10\% SDS-PAGE and transferred to PVDF membrane (Millipore Corporation, USA) overnight at $4{ }^{\circ} \mathrm{C}$ : the membrane was then blocked in $5 \%$ non-fat milk. The membrane was probed separately with the primary antibodies for GAPDH-HRP (1:1000, Kangcheng, Shanghai, China) and rabbit antihuman HMGCR (1:1000, Cell Signaling), and secondary antibodies (1:10000, Santa Cruz). Signal was detected using an ECL Kit (Millipore, USA) and developed on X-ray film. Protein bands were detected by ChemiDoc XRS systems and Quality One 4. 6.1 (Bio-Rad, Hercules, CA) software, and GAPDH antibody was used as the internal control.

\section{Statistical analysis}

All data were presented as means \pm SEM, obtained from at least three separate experiments, and one representative image was selected for presentation in the figures. One-way analysis of variance followed by Dunnett's test was used for comparison among groups (SPSS computer software version 13.0). $\quad P<0.05$ was considered significant.

\section{Results}

Effects of CRO, CGA, GEN, and QUE on HepG2 cell viability

We examined the cytotoxicity of CRO, CGA, GEN, and QUE to determine suitable concentrations for the treatment of HepG2 cells. Results showed that $100 \mu \mathrm{M}$ $\mathrm{CRO}, \mathrm{CGA}$, and GEN, and $\leq 10 \mu \mathrm{M}$ QUE had no inhibitory effect on HepG2 cell viability after 24 or 48 h of treatment (Fig. 2). Therefore, subsequent experiments used the following concentrations: $10 \mu \mathrm{mol} / \mathrm{L}$ SIM, $1 \mu \mathrm{mol} / \mathrm{L}$ CRO, $30 \mu \mathrm{mol} / \mathrm{L}$ CGA, $10 \mu \mathrm{mol} / \mathrm{L}$ GEN, $10 \mu \mathrm{mol} / \mathrm{L}$ QUE, and a combination of $1 \mu \mathrm{mol} / \mathrm{L}$ CRO, $30 \mu \mathrm{mol} / \mathrm{L} \mathrm{CGA}, 10 \mu \mathrm{mol} / \mathrm{L}$ GEN, and $10 \mu \mathrm{mol} / \mathrm{L}$ QUE (CCGQ), consistent with concentrations used in previous studies [18-21].

\section{CRO, CGA, GEN, QUE, and CCGQ inhibit lipid accumulation in HepG2 cells}

To test whether drugs affected lipid deposition, we examined lipid droplets in HepG2 cells using Oil red O staining. Compared with the control group, we found prominent lipid accumulation in the cytoplasm of HepG2 cells, using $0.1 \mathrm{mmol} / \mathrm{L}$ of oleate. Compared with the oleate group, treatment with SIM, CRO, CGA, GEN, and CCGQ significantly attenuated the accumulation of lipid droplets, however, QUE alone did not induce notable inhibition (Fig. 3a, b). To further assess lipid deposition, we determined TC and TG content in the culture medium of HepG2 cells (Fig. 3c, d). Consistent with Oil red $\mathrm{O}$ findings, all drugs elevated extracellular TC and TG levels after treatment for 24 or $48 \mathrm{~h}$. CCGQ and CRO induced significant increases in concentrations of secreted TC in cells treated for $48 \mathrm{~h}$, which were greater than effects produced by any other single drug. Compared with the SIM group, treatment with CCGQ for 24 or $48 \mathrm{~h}$ significantly increased extracellular TC and TG content $(p<0.05)$. These results indicate that combined treatment with CCGQ results in a much greater decrease in lipid accumulation in HepG2 cells than treatment with the drugs individually.

\section{Effect of CRO, CGA, GEN, QUE and CCGQ on cholesterol metabolism-related gene expression}

In order to further clarify the mechanism responsible for the changes in cholesterol levels of HepG2 cells, we next examined the mRNA expression levels of cholesterol metabolism-related enzymes (results shown in Fig. 4). All drugs increased ABCA1 mRNA expression in comparison with the control group, and had significantly greater effects than SIM treatment. CYP7A1 mRNA expression was significantly enhanced by treatment with SIM, CCGQ, CGA, and GEN, but was comparable to the control group in CRO-treated cells, and was lower than levels in all other groups in QUE-treated cells. All individual drugs except GEN significantly decreased HMGCR mRNA expression.

Numerous studies indicate that AMPK, LXR $\alpha$ and SREBP2 play key roles in regulating cholesterol homeostasis. As shown in Fig. 4, treatment with SIM, CCGQ, 

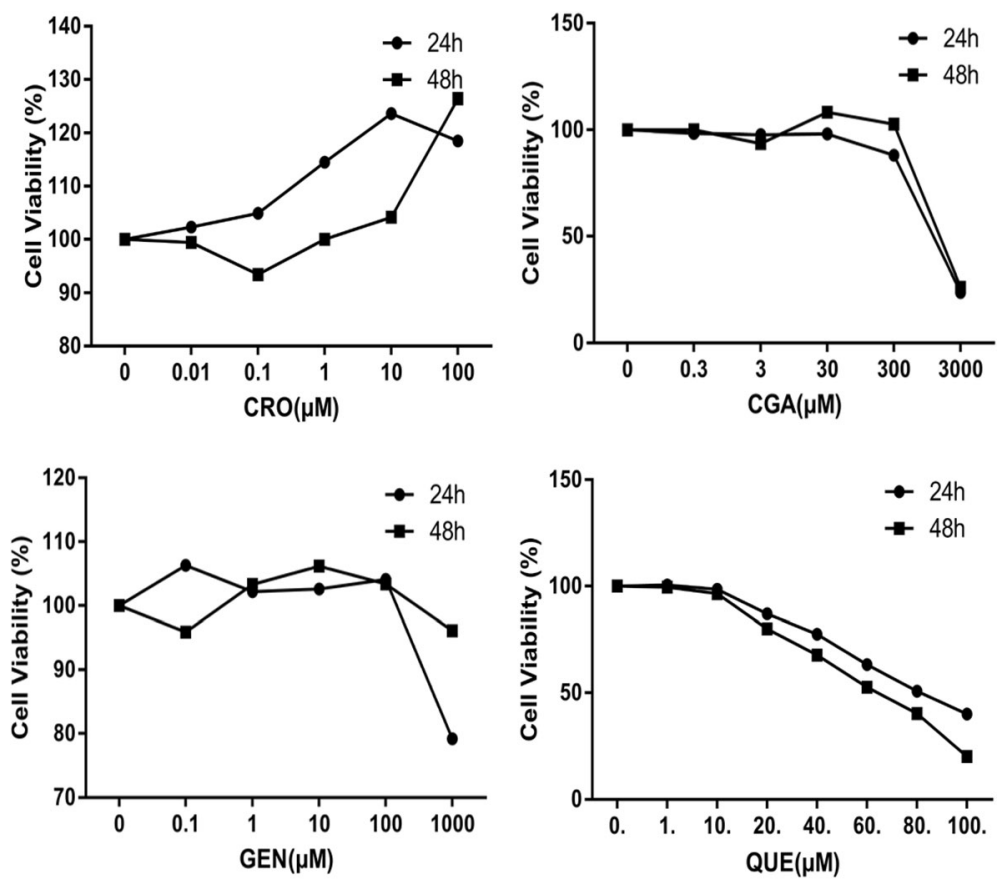

Fig. 2 The effects of different concentrations of CRO, CGA, GEN and QUE on the viability of HepG2 cells for $24 \mathrm{~h}$ or 48 h. Data are expressed as mean \pm SEM from at least five independent experiments

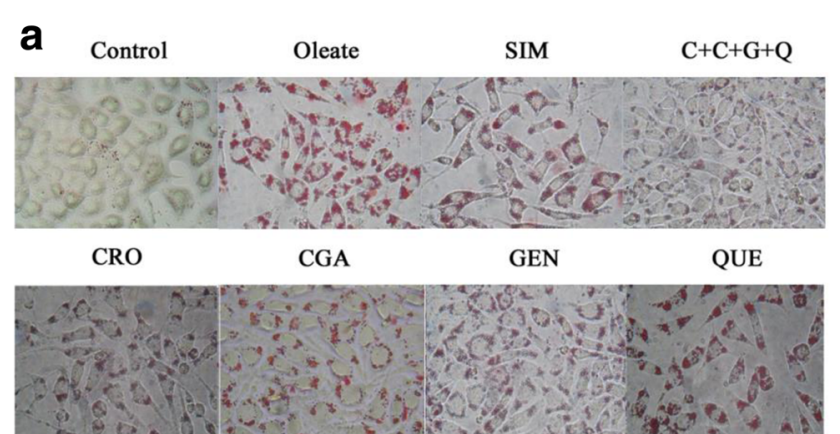

b

C

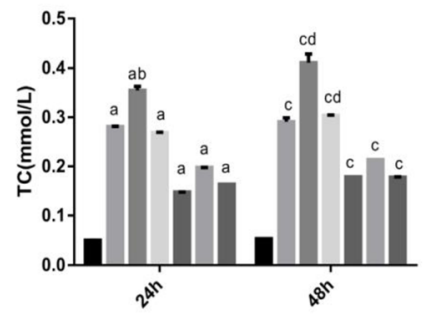

Time (h) d

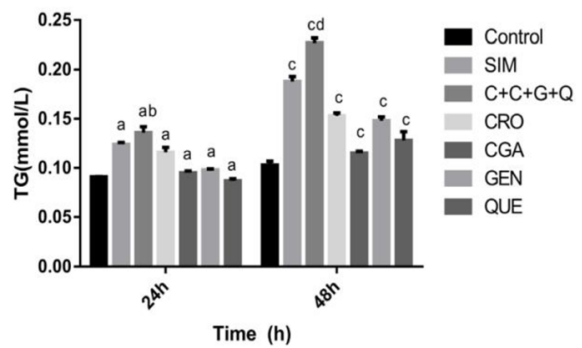

Fig. 3 The effects of CRO, CGA, GEN, QUE and $C+C+G+Q$ on lipid content in HepG2 cells. HepG2 cells were treated with Oleate $(0.1 \mathrm{mmol} / \mathrm{L})$, $\operatorname{SIM}(10 \mu \mathrm{mol} / \mathrm{L}), \mathrm{CRO}(1 \mu \mathrm{mol} / \mathrm{L}), \mathrm{CGA}(30 \mu \mathrm{mol} / \mathrm{L}), \mathrm{GEN}(10 \mu \mathrm{mol} / \mathrm{L}), \mathrm{QUE}(10 \mu \mathrm{mol} / \mathrm{L})$ and $\mathrm{C}+\mathrm{C}+\mathrm{G}+\mathrm{Q}(1 \mu \mathrm{mol} / \mathrm{L}+30 \mu \mathrm{mol} / \mathrm{L}+10 \mu \mathrm{mol} / \mathrm{L}+$ $10 \mu \mathrm{mol} / \mathrm{L}$ ) for $24 \mathrm{~h}$ or $48 \mathrm{~h}$. a After $48 \mathrm{~h}$ incubation with different drugs, the images of cells were observed by microscope at $250 \times$ original magnification showing lipid accumulation in cells stained by Oil red O. b The comparison of integral optical density (IOD) for Oil red staining in cells. Effects of different drugs on the secretion of (c) TC and (d) TG were observed by HepG2 cells in minimum essential medium. Data are expressed as mean \pm SEM from at least four independent experiments. ${ }^{*} P<0.05$ vs. control, ${ }^{\#} P<0.05$ vs. Oleate. After $24 \mathrm{~h},{ }^{a} P<0.05$ vs. control, ${ }^{\mathrm{b}} p<0.05$ vs. SIM. After $48 \mathrm{~h},{ }^{\mathrm{c}} p<0.05$ vs. control, ${ }^{\mathrm{d}} p<0.05$ vs. SIM 

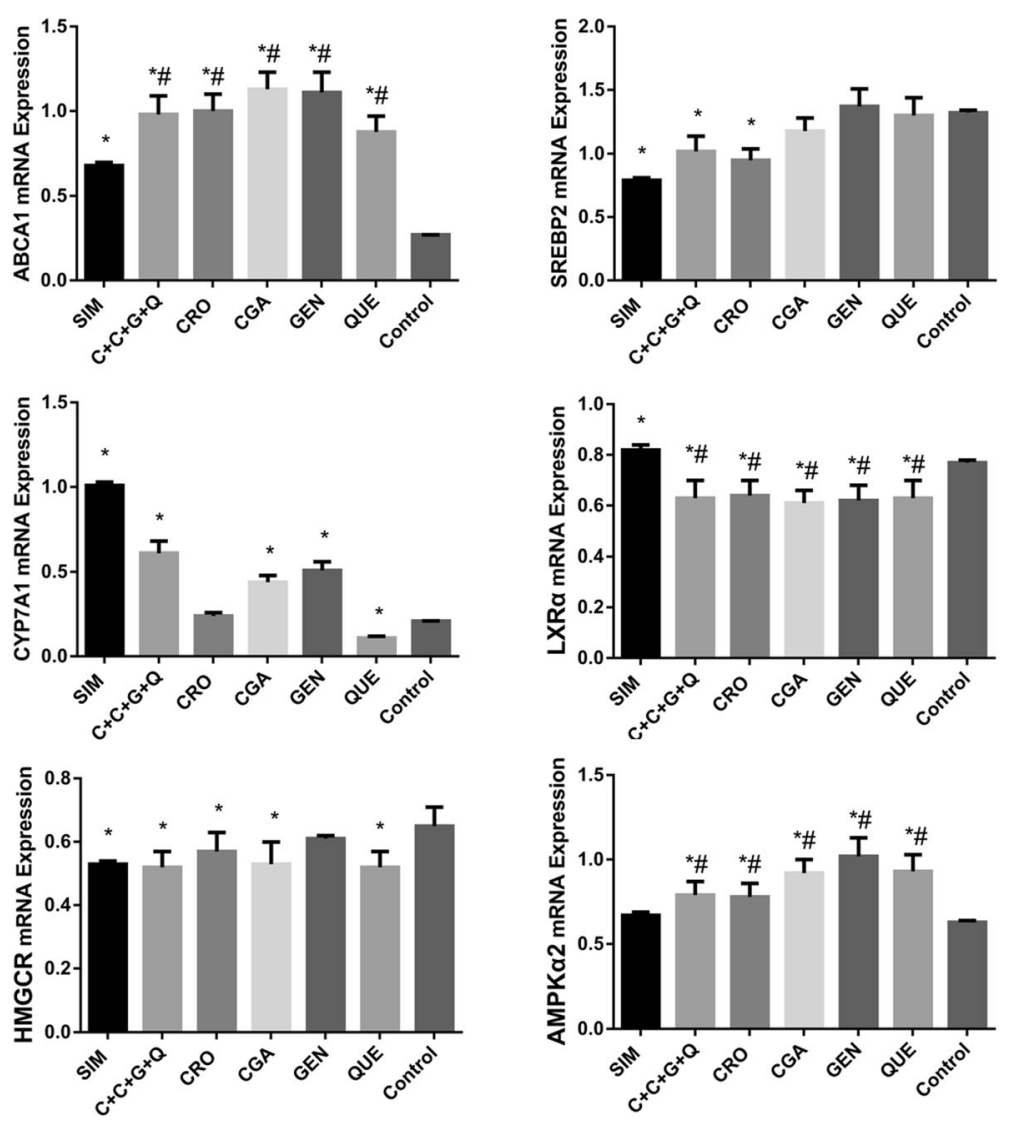

$\begin{array}{llllllll}1 & 2 & 3 & 4 & 5 & 6 & 7\end{array}$

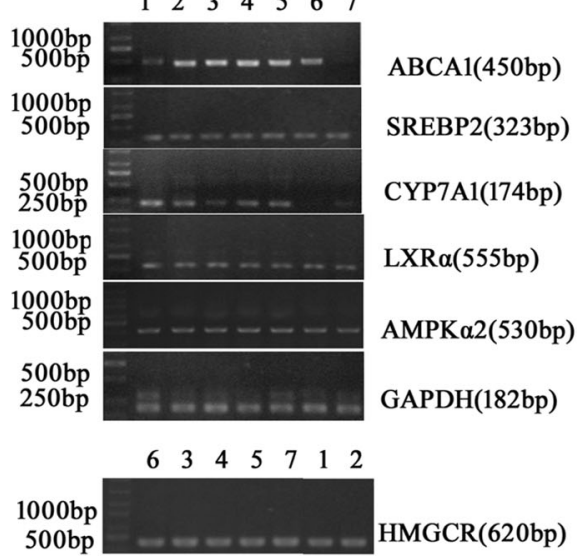

Fig. 4 mRNA expression levels of the regulation cholesterol activities associated genes ABCA1, SREBP2, CYP7A1, LXRa, AMPKa2 and HMGCR in HepG2 cells. All genes were normalized with GAPDH. HepG2 cells were treated with (1) SIM (10 $\mu \mathrm{mol} / \mathrm{L}),(2) \mathrm{C}+\mathrm{C}+\mathrm{G}+\mathrm{Q}(1 \mu \mathrm{mol} / \mathrm{L}+30 \mu \mathrm{mol} / \mathrm{L}$ $+10 \mu \mathrm{mol} / \mathrm{L}+10 \mu \mathrm{mol} / \mathrm{L})$ (3) CRO (1 $\mu \mathrm{mol} / \mathrm{L})$, (4) CGA $(30 \mu \mathrm{mol} / \mathrm{L})$, (5) GEN $(10 \mu \mathrm{mol} / \mathrm{L})$, (6) QUE $(10 \mu \mathrm{mol} / \mathrm{L})$ and no drug for (7) Control respectively for $48 \mathrm{~h}$. Data represent as mean \pm SEM of three independent experiments. ${ }^{*} P<0.05$ vs. control, ${ }^{\#} P<0.05$ vs. SIM

or CRO significantly inhibited SREBP2 expression compared to the control group, while the other drugs had no significant effect on SREBP2 expression. Treatment with SIM significantly up-regulated LXR $\alpha$ mRNA expression, while the opposite effect was observed in cells treated with all other drugs. All drugs except SIM enhanced AMPK $2 \alpha$ expression compared with the control group.
CRO, CGA, GEN, QUE, and CCGQ suppress HMGCR protein expression in HepG2 cells

We also examined intracellular localization and expression of HMGCR protein by immunostaining and western blotting, after treatment for $48 \mathrm{~h}$ with the different drugs. Figure 5 demonstrates prominent accumulation of brown HMGCR granules localized in the cytoplasm 

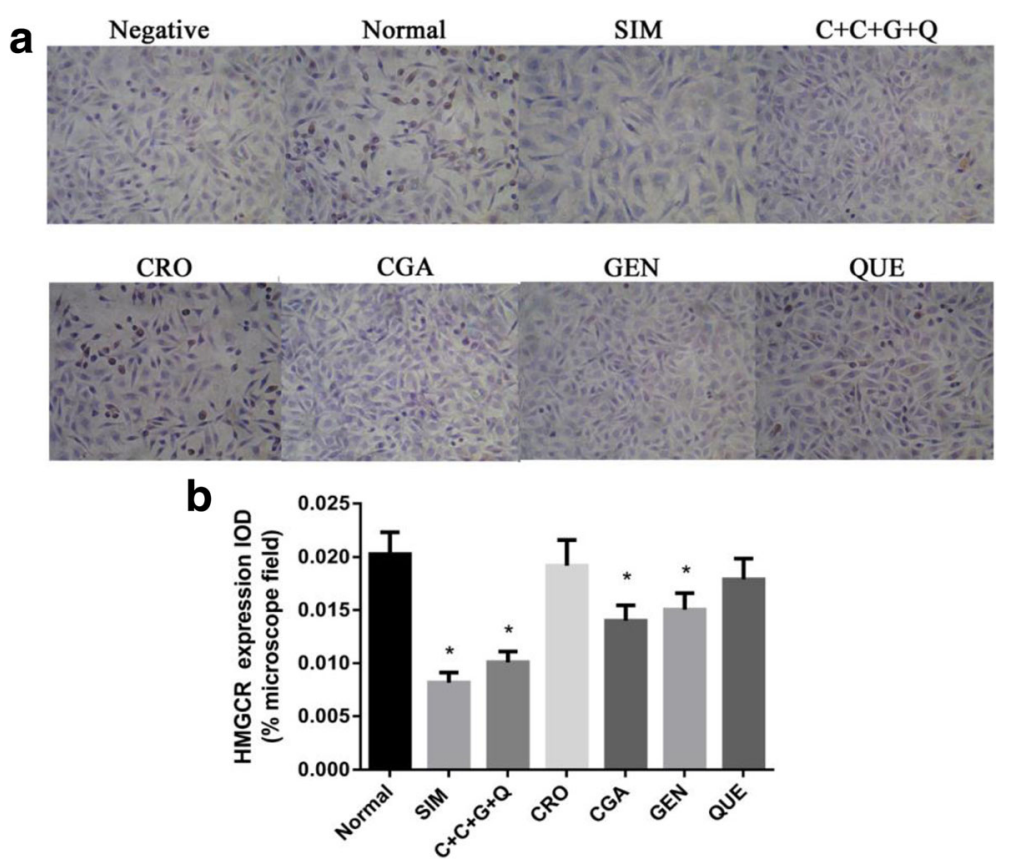

Fig. 5 Expression of HMGCR in HepG2 cells. a Representative immunocytochemical images of HMGCR expression in cells. HepG2 cells were treated with SIM $(10 \mu \mathrm{mol} / \mathrm{L}), C+C+\mathrm{G}+\mathrm{Q}(1 \mu \mathrm{mol} / \mathrm{L}+30 \mu \mathrm{mol} / \mathrm{L}+10 \mu \mathrm{mol} / \mathrm{L}+10 \mu \mathrm{mol} / \mathrm{L}), C R O(1 \mu \mathrm{mol} / \mathrm{L}), \mathrm{CGA}(30 \mu \mathrm{mol} / \mathrm{L}), \mathrm{GEN}(10 \mu \mathrm{mol} / \mathrm{L})$ and QUE $(10 \mu \mathrm{mol} / \mathrm{L})$ for $48 \mathrm{~h}$ respectively, and treated with PBS instead of the primary antibody of HMGCR for negative control, and with no drug for normal control. The brown granules in the cytoplasm represent HMGCR positive staining results. $\mathbf{b}$ The bar chart showing the comparison of the IOD for HMGCR expression in cells. Data represent as mean \pm SEM of three independent experiments. ${ }^{*} P<0.05$ vs. control, ${ }^{\#} P$ $<0.05$ vs. SIM

of control, CRO, and QUE cells. Treatment with SIM, CGA, GEN, or CCGQ markedly reduced HMGCR expression compared with untreated cells. Consistent with these results, as shown in Fig. 6, HMGCR protein expression decreased in all treatment groups compared to the control group, but not as much as the SIM group. In particular, CCGQ combined treatment resulted in a much greater decrease in HMGCR expression than individual treatments.

\section{Discussion and conclusion}

CRO, CGA, GEN and QUE are known to possess antiobesity properties, in particular hypolipidemic effects, and have been widely used for treatment of obesityrelated metabolic diseases [6,7]. This is the first study to demonstrate that combined CCGQ treatment of HepG2 cells resulted in a marked decrease in lipid deposition in comparison to individual CRO, CGA, GEN, and QUE treatment, determined by Oil red $\mathrm{O}$ staining, and triglyceride and total cholesterol assays. In addition, with respect to the rate-limiting enzyme for cholesterol synthesis, pretreatment with CCGQ for $48 \mathrm{~h}$ had a potent decreasing effect on HMGCR compared to individual drugs, determined by immunohistochemistry and western-blot analysis, and induced genes related to cholesterol metabolism.
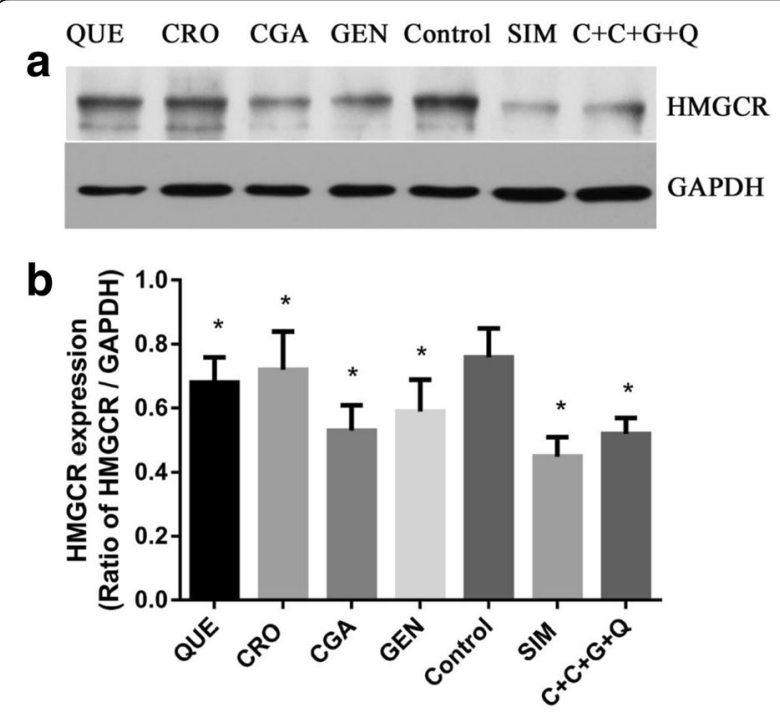

Fig. 6 All drugs and their combination suppress HMGCR protein expression in HepG2 cells. a Western blotting analysis of HMGCR, (b) The densitonmetric scanning of HMGCR after normalization with GAPDH. HepG2 cells from 3 set of each group were pooled separately and homogenates was prepared for western blotting analysis of HMGCR. HepG2 cells were treated with QUE $(10 \mu \mathrm{mol} / \mathrm{L})$, CRO $(1 \mu \mathrm{mol} / \mathrm{L}), C G A(30 \mu \mathrm{mol} / \mathrm{L}), \mathrm{GEN}(10 \mu \mathrm{mol} / \mathrm{L})$, SIM $(10 \mu \mathrm{mol} / \mathrm{L})$ and $C+C+G+Q(1 \mu \mathrm{mol} / \mathrm{L}+30 \mu \mathrm{mol} / \mathrm{L}+10 \mu \mathrm{mol} / \mathrm{L}+10 \mu \mathrm{mol} / \mathrm{L})$ for $48 \mathrm{~h}$ respectively. Data represent as mean \pm SEM of three independent experiments. ${ }^{*} P<0.05$ vs. control 
Similar to gardenia fruit, HPLC analysis showed that Eucommia ulmoides Oliver (eucommia) leaf mainly consists of CGA, in addition to GEN and QUE [22]. We previously demonstrated that CGA-enriched extract (CAEF) from eucommia leaf was more effective in lowering lipid levels than the same concentration of CGA, and deduced that the hypolipidemic effect of CAEF may be attributed to the synergistic effects of its other components [18]. We therefore selected CRO, CGA, GEN, and QUE for HepG2 cell treatment, to observe their synergistic lipid-decreasing effects. Neutral lipid drops were apparently decreased by all drugs except QUE: these results were further supported by the determination of TC and TG content in the supernatant of HepG2 cells, and combinations of these natural compounds were more effective than SIM or each individual compound. These positive outcomes may result from synergistic interactions between the different bioactive phytochemicals.

The liver plays a central role in cholesterol metabolism. Cholesterol homeostasis is governed by several genes, including HMGCR, CYP7A1, ABCA1, SREBPs, LXR, and AMPK. These genes maintain a complex network involving cholesterol uptake, synthesis, intracellular transport, and excretion [23, 24]. HMGCR is responsible for cholesterol synthesis [25], CYP7A1 catalyzes the conversion of cholesterol into bile acids, ABCA1 is involved in high-density lipoprotein (HDL) formation and facilitates the efflux of free cholesterol, SREBP2 positively regulates cholesterol biosynthesis genes, and activation of LXR is associated with increased lipogenesis and fat accumulation. HMGCR, CYP7A1, ABCA1, and SREBPs are all target genes of LXR [2628]. AMPK, as an upstream kinase in lipid metabolism regulation, inhibits transcriptional activity of SREBPs [29], as well as ligand-induced LXR activity and production of endogenous LXR ligands [30]. The protective effects of CRO, CGA, QUE, GEN and their combination against hepatocytic cholesterol accumulation may therefore be studied by measuring changes in expression of these key hepatic transcription mRNAs.

Our data show that ABCA1, CYP7A1, and AMPK $2 \alpha$ expression in HepG2 cells significantly increased in CCGQ-treated cells; however, HMGCR, SREBP2 and LXR $\alpha$ mRNA levels were significantly lower than those of the control group. Gene expression in the SIM group was similar to that of the CCGQ group, aside from upregulated LXR $\alpha$ and a lack of increase in AMPK $2 \alpha$ expression in SIM-treated cells. Again, similar effects were observed for ABCA1, AMPK $2 \alpha$, and LXR $\alpha$ mRNA expression in HepG2 cells, after treatment with CRO, CGA, QUE, and GEN. Nonetheless, we observed that CRO, CGA, and QUE also significantly decreased HMGCR mRNA expression, although this was not observed for the GEN group. Interestingly, out of all four phytochemicals, only $\mathrm{CRO}$ induced dramatically lower SREBP2 mRNA expression than the control group. On measuring the abundance of the CYP7A1 gene, responsible for the synthesis of bile acids, we observed significant differences between CRO-, CGA-, GEN-, and QUE-treated cells. CYP7A1 expression was repressed in the QUE group, CGA and GEN increased CYP7A1 expression, and no change was noted in the CRO group.

The role for QUE in suppressing LXR $\alpha$ gene expression and modulating lipid accumulation has previously been described in Huh7 cells [31]. The current study is the first demonstration that CRO, CGA, QUE, GEN, and CCGQ all significantly inhibited LXR $\alpha$ mRNA expression in HepG2 cells, in agreement with previous data from our group [18]. Although the expression of genes involved in cholesterol biosynthesis, bile acid synthesis, and cholesterol efflux is regulated by LXR, our data show that CCGQ up-regulated some genes involved in these processes (CYP7A1 and ABCA1) and downregulated others (HMGCR and SREBP2). In recent reports, AMPK activation increased ABCA1 mRNA and protein expression, increasing the cholesterol efflux capacity of macrophages [32, 33]. Activation of AMPK by sulfated low molecular weight guluronate was linked to up-regulation of CYP7A1 in HepG2 cells [34]. Based on these studies, the up-regulation of CYP7A1 and ABCA1 may be attributed to AMPK activation by CCGQ. Further studies are required to fully understand the mechanism of AMPK activation.

In our study, HMGCR protein expression, measured by immunocytochemistry and western blot and confirmed by PCR, was inhibited to a greater extent in the CCGQ group than in cells treated with the individual drugs, suggesting that the four phytochemicals may be more efficient in combination than separately. These data are consistent with the reduction in hepatic lipid accumulation observed in Oil red $\mathrm{O}$ staining and lipid content analysis. Analysis of the relative expression of related genes, based on hepatic lipid concentration, also showed that CCGQ dramatically decreased hepatic lipid accumulation to a greater extent than the individual drugs.

Based on our observations, the preventative effect of CCGQ on lipid accumulation in HepG2 cells was considerably greater than that of SIM. Statins are the preferred drugs for treatment of hyperlipemia. However, evidence that they cause hazardous side effects, and are effective in only one-third of patients, highlights the need for alternative therapies [35].

The experimental findings of the present study primarily revealed that synergistic interactions between combined CRO, CGA, GEN, and QUE demonstrated 
positive effects against hepatic lipid accumulation. The anti-hyperlipidemic effect of these phytochemicals appears to be mediated by the modulation of AMPK, LXR $\alpha$, and associated genes engaged in cholesterol synthesis, metabolism, and efflux. To our knowledge, this is the first report demonstrating the synergistic lipidlowering actions of CRO, CGA, GEN and QUE. Although results from in vitro experiments cannot be directly extrapolated to anti-obesity and lipid-modulating clinical effects of gardenia fruit [16] and eucommia leaf [36], such studies will assist in elucidating the antihyperlipidemic mechanisms of their constituent compounds, either individually or in combination treatments. These results also suggest that combining active ingredients in traditional herbal medicine, to enhance their curative effects, may potentially improve hyperlipemia and further prevent obesity-related complications. However, more detailed studies are required to validate their synergistic interactions.

\section{Abbreviations}

ABCA1: ATP-binding cassette transporter; AMPKa2: AMP-activated protein kinase 2a; CCGQ: The combination of CRO, CGA, GEN, and QUE; CGA: Chlorogenic acid; CRO: Crocin; CYP7A1: Cholesterol 7a-hydroxylase; DMSO: Dimethyl sulfoxide; GAPDH: Glyceraldehyde-3-phosphate dehydrogenase; GEN: Geniposide; HMGCR: 3-hydroxy-3-methylglutarylcoenzyme; LXRa: Liver X receptor alpha; QUE: Quercetin; SIM: Simvastatin; SREBP2: Sterol regulatory element binding protein 2; TC: Total cholesterol; TG: Triacylglycerol

\section{Acknowledgements}

We thank Zunhai Campus of Zunyi Medical University for providing necessary facilities.

\section{Funding}

This study was supported by Zhuhai Premier-Discipline Enhancement Scheme of Pharmacology, Zhuhai Campus of Zunyi Medical University, The project from Guizhou Provincial Modernization of Traditional Chinese Medicine Foundation of China (Grant No. QKHZY [2013]3018), The Science and Technology Foundation of Guizhou Province of China (QKHJC [2017]1220), and The Project Natural Science Foundation of China (No. 81760697).

\section{Availability of data and materials}

All data and materials are contained and described within the manuscript.

\section{Authors' contributions}

LWN were responsible for the design of study and providing research fund LWN and MZT analyzed the data and provided technical guidance. LEN, XY and $Z Y Y$ made experimental operation and wrote the manuscript. LYQ, DXS, $Z M, Z C C, H Z X, H J Y, X L$ and LJM, participated in cell experimental and statistical analysis. All authors read and approved the final manuscript.

\section{Ethics approval and consent to participate} Not Applicable.

\section{Consent for publication}

Not Applicable.

\section{Competing interests}

The authors declare that they have no competing interests.

\section{Publisher's Note}

Springer Nature remains neutral with regard to jurisdictional claims in published maps and institutional affiliations.

\section{Author details}

'Zhuhai Campus, Zunyi Medical University, Jinwan District, Zhuhai 519041, Guangdong, China. ${ }^{2}$ Pharmaceutical Preparation Section, Guizhou Province People's Hospital, Guiyang, Guizhou, China.

Received: 21 September 2017 Accepted: 26 March 2018

Published online: 05 April 2018

\section{References}

1. Bener A, Yousafzai MT, Darwish S, Al-Hamaq AO, Nasralla EA, Abdul-Ghani M. Obesity index that better predict metabolic syndrome: body mass index, waist circumference, waist hip ratio, or waist height ratio. J Obes. 2013;2013: 269038.

2. Stefan N, Haring HU, Hu FB, Schulze MB. Metabolically healthy obesity: epidemiology, mechanisms, and clinical implications. Lancet Diabetes Endocrinol. 2013;1:152-62.

3. Walther TC, Farese RV Jr. Lipid droplets and cellular lipid metabolism. Annu Rev Biochem. 2012:81:687-714.

4. Lodhi IJ, Yin L, Jensen-Urstad AP, Funai K, Coleman T, Baird JH, et al. Inhibiting adipose tissue lipogenesis reprograms thermogenesis and PPARgamma activation to decrease diet-induced obesity. Cell Metab. 2012; 16:189-201.

5. Ramasamy I. Update on the molecular biology of dyslipidemias. Clin Chim Acta. 2016:454:143-85.

6. Hassan HA, El-Gharib NE. Obesity and clinical riskiness relationship: therapeutic management by dietary antioxidant supplementation-a review. Appl Biochem Biotechnol. 2015;176:647-69.

7. Yun JW. Possible anti-obesity therapeutics from nature-a review. Phytochemistry. 2010;71:1625-41.

8. Wang S, Moustaid-Moussa N, Chen L, Mo H, Shastri A, Su R, et al. Novel insights of dietary polyphenols and obesity. J Nutr Biochem. 2014;25:1-18.

9. Lee IA, Lee JH, Baek NI, Kim DH. Antihyperlipidemic effect of crocin isolated from the fructus of Gardenia jasminoides and its metabolite crocetin. Bio Pharm Bull. 2005;28:2106-10.

10. Shirali S, Zahra Bathaie S, Nakhjavani M. Effect of crocin on the insulin resistance and lipid profile of streptozotocin-induced diabetic rats. Phytother Res. 2013;27(7):1042.

11. Meng S, Cao J, Feng Q, Peng J, Hu Y. Roles of chlorogenic acid on regulating glucose and lipids metabolism: a review. Evid Based Complement Alternat Med. 2013;2013:801457.

12. Wan CW, Wong CN, Pin WK, Wong MH, Kwok CY, Chan RY, et al. Chlorogenic acid exhibits cholesterol lowering and fatty liver attenuating properties by up-regulating the gene expression of PPAR-alpha in hypercholesterolemic rats induced with a high-cholesterol diet. Phytother Res. 2013;27:545-51.

13. Zhang $\mathrm{WL}$, Zhu L, Jiang JG. Active ingredients from natural botanicals in the treatment of obesity. Obes Rev. 2014;15:957-67.

14. D'Andrea G. Quercetin: A flavonol with multifaceted therapeutic applications? Fitoterapia. 2015;106:256-71.

15. Nabavi SF, Russo GL, Daglia M, Nabavi SM. Role of quercetin as an alternative for obesity treatment: you are what you eat! Food Chem. 2015; 179:305-10

16. Shin JS, Huh YS. Effect of intake of gardenia fruits and combined exercise of middle-aged obese women on hormones regulating energy metabolism. J Exerc Nutrition Biochem. 2014;18:41-9.

17. Wang YR, Chen Y, Deng L, Cai SN, Liu J, Li WN, et al. Systematic separation and purification of Iridoid glycosides and Crocetin derivatives from Gardenia jasminoides Ellis by high-speed counter-current chromatography. Phytochem Anal. 2015;26:202-8.

18. Hao S, Xiao Y, Lin Y, Mo ZT, Chen Y, Peng XF, et al. Chlorogenic acidenriched extract from Eucommia ulmoides leaves inhibits hepatic lipid accumulation through regulation of cholesterol metabolism in HepG2 cells. Pharma. Biol. 2016;54:251-9.

19. Guo LX, Zheng XX, Liu JH, Yin ZY. Geniposide suppresses hepatic glucose production via AMPK in HepG2 cells. Biol Pharma Bull. 2016;39: 484-91.

20. Maurya AK, Vinayak M. Anticarcinogenic action of quercetin by downregulation of phosphatidylinositol 3-kinase (PI3K) and protein kinase C (PKC) via induction of p53 in hepatocellular carcinoma (HepG2) cell line. Mol Biol Rep. 2015;42:1419-29. 
21. Xu GL, Qian ZY, Yu SQ, Gong ZN, Shen XC. Evidence of crocin against endothelial injury induced by hydrogen peroxide in vitro. J Asian Nat Prod Res. 2006;8:79-85.

22. Zhang YP, Peng MJ, Liu LL, Shi SY, Peng S. Screening, identification, and potential interaction of active compounds from Eucommia ulmodies leaves binding with bovine serum albumin. J Agric Food Chem. 2012;60:3119-25.

23. Arguello G, Balboa E, Arrese M, Zanlungo S. Recent insights on the role of cholesterol in non-alcoholic fatty liver disease. Biochim Biophys Acta. 2015; 1852:1765-78

24. Lee SD, Tontonoz $P$. Liver $X$ receptors at the intersection of lipid metabolism and atherogenesis. Atherosclerosis. 2015;242:29-36.

25. Ness GC. Physiological feedback regulation of cholesterol biosynthesis: role of translational control of hepatic HMG-CoA reductase and possible involvement of oxylanosterols. Biochim Biophys Acta. 2015;1851:667-73.

26. Calkin AC, Tontonoz P. Transcriptional integration of metabolism by the nuclear sterol-activated receptors LXR and FXR. Nat Rev Mol Cell Biol. 2012; 13:213-24.

27. Musso G, Gambino R, Cassader M. Cholesterol metabolism and the pathogenesis of non-alcoholic steatohepatitis. Prog Lipid Res. 2013;52:17591.

28. Vaisman BL, Lambert G, Amar M, Joyce C, Ito T, Shamburek RD, et al. ABCA1 overexpression leads to hyperalphalipoproteinemia and increased biliary cholesterol excretion in transgenic mice. J Clin Inves. 2001;108:303-9.

29. Li Y, Xu S, Mihaylova MM, Zheng B, Hou X, Jiang B, et al. AMPK phosphorylates and inhibits SREBP activity to attenuate hepatic steatosis and atherosclerosis in diet-induced insulin-resistant mice. Cell Metab. 2011; 13:376-88.

30. Yap F, Craddock L, Yang J. Mechanism of AMPK suppression of LXRdependent Srebp-1c transcription. Int J Biol Sci. 2011;7:645-50.

31. Pisonero-Vaquero S, Garcia-Mediavilla MV, Jorquera F, Majano PL, Benet M, Jover R, et al. Modulation of PI3K-LXRalpha-dependent lipogenesis mediated by oxidative/nitrosative stress contributes to inhibition of HCV replication by quercetin. Lab Invest. 2014;94:262-74.

32. Fullerton MD, Ford RJ, McGregor CP, LeBlond ND, Snider SA, Stypa SA, et al. Salicylate improves macrophage cholesterol homeostasis via activation of AMPK. J Lipid Res. 2015;56:1025-33.

33. Kemmerer M, Wittig I, Richter F, Brune B, Namgaladze D. AMPK activates LXRalpha and ABCA1 expression in human macrophages. Int Biochem Cell Biol. 2016:78:1-9.

34. Liu X, Hao JJ, Zhang L, Zhao X, He XX, Li MM, et al. Activated AMPK explains hypolipidemic effects of sulfated low molecular weight guluronate on HepG2 cells. Eur J Med Chem. 2014;85:304-10.

35. Mihaylova B, Emberson J, Blackwell L, Keech A, Simes J, Barnes EH, et al. The effects of lowering LDL cholesterol with statin therapy in people at low risk of vascular disease: meta-analysis of individual data from 27 randomised trials. Lancet. 2012;380:581-90.

36. ZHOU Chang-jiang HL, LI kun, HOU Xian-qin, LIU Xi-long, LIU Ri-Xu, WENG wen-cai, et al. The inhibitive effect of Eucommia ulmoides leaves extract on abdominal fat. Inter J Endocrinology Metab. 2011;31:3.

\section{Submit your next manuscript to BioMed Central and we will help you at every step:}

- We accept pre-submission inquiries

- Our selector tool helps you to find the most relevant journal

- We provide round the clock customer support

- Convenient online submission

- Thorough peer review

- Inclusion in PubMed and all major indexing services

- Maximum visibility for your research

Submit your manuscript at www.biomedcentral.com/submit

BioMed Central 